\title{
Post-dural puncture headache incidence after cerebrospinal fluid aspiration. A prospective observational study
}

\author{
Incidência de cefaleia pós-punção dural após aspiração do líquido cefalorraquidiano. \\ Um estudo observacional prospectivo
}

Rodrigo Tomazini MARTINS ${ }^{1,2}$, Barbara TOSON ${ }^{3}$, Ricardo Krause Martinez de SOUZA',4, Pedro Andre KOWACS

\begin{abstract}
Background: Post-dural puncture headache (PDPH) is an iatrogenic condition following lumbar puncture (LP). Incidence is variable and often associated with young females. Technical features of the procedure (i.e. needle gauge) have been investigated; however there is no investigation on the method of cerebrospinal fluid (CSF) collection. Objective: To investigate whether mild CSF aspiration is associated with increased PDPH in selected patients. Methods: 336 subjects were eligible to the study. Data on 237 patients from a tertiary neurology hospital who underwent diagnostic LP from February 2010 to December 2012 were analysed. Patient demographics, lumbar puncture method, CSF biochemical characteristics, opening pressures, and a follow-up inquire on PDPH occurrence were collected. CSF was collected either by allowing free flow or by mild aspiration. Results: The aspiration arm $(n=163)$ was comprised of $55.8 \%$ females with mean age of 52(35-69) years. Sex distribution was not different between the two arms ( $p=0.191)$. A significant larger amount of CSF was obtained in the aspiration arm $(p=0.011)$. The incidence of PDPH in the aspiration arm was $16.5 \%$ versus $20.2 \%$ in the free flow arm, not statistically significant $(p=0.489)$. No relevant associations emerged from the analyses in the subgroup aged <65 years. Conclusions: Aspiration of the CSF during LP was not associated with increased rates of PDPH compared to the standard method, particularly when larger amounts of CSF are required and ideal conditions are met. This is the first study looking into this matter, aiming to add safety to the procedure. Further randomized trials are required.
\end{abstract}

Keywords: cerebrospinal fluid; headache; post-dural puncture headache; spinal puncture.

\section{RESUMO}

Introdução: Cefaleia pós-punção dural (CPPD) é uma condição iatrogênica após punção lombar (LP). Incidência é variável; frequentemente associada a mulheres jovens. Características técnicas do procedimento (ex: calibre da agulha) foram investigadas; no entanto, não há investigação sobre o método de coleta do líquido cefalorraquidiano (LCR). Objetivo: Avaliar se aspiração leve do LCR está associada ao aumento da CPPD em pacientes selecionados. Métodos: 336 indivíduos foram elegíveis para o estudo. Dados de 237 pacientes em um hospital neurológico terciário que foram submetidos à PL diagnóstica de fevereiro de 2010 a dezembro de 2012 foram analisados. Coletamos dados demográficos dos pacientes, método da PL, características bioquímicas do LCR, pressões de abertura e ocorrência da CPPD. Todos as PLs ocorreram em decúbito lateral. O LCR foi coletado permitindo livre fluxo ou aspiração leve. Resultados: 0 grupo aspiração ( $n=163)$ apresentava 55,8\% de mulheres, idade média de 52(35-69) anos. A distribuição por sexo não foi diferente entre os dois grupos $(p=0,191)$. Uma quantidade maior de LCR foi obtida no grupo aspiração $(p=0,011)$. A incidência de CPPD no grupo de aspiração foi de 16,5\% versus 20,2\% no fluxo livre, não estatisticamente significante $(p=0,489)$. Nenhuma associação emergiu das análises no subgrupo com idades <65 anos. Conclusões: A aspiração do LCR durante PL não está associada ao aumento da CPPD em comparação com a método padrão, particularmente quando quantidades maiores de LCR são necessárias e condições ideais são satisfeitas. Este é o primeiro estudo a investigar o topico, visando aumentar a segurança do procedimento. Necessita-se futuros estudos randomizados.

Palavras-chave: líquido cefalorraquidiano; cefaleia; cefaleia pós-punção dural; punção espinal.

\footnotetext{
'Instituto de Neurologia de Curitiba (INC), Departamento de Neurologia, Curitiba PR, Brazil.

${ }^{2}$ Gosford Hospital, Neurology Department, NSW, Australia.

${ }^{3}$ Neuroscience Research Australia (NeuRA), NSW, Australia.

${ }^{4}$ Centro de Memória de Curitiba (CMC), Curitiba PR, Brazil.

Rodrigo Tomazini MARTINS (iD) https://orcid.org/0000-0002-6415-0310; Barbara TOSON (iD) https://orcid.org/0000-0001-6661-9971;

Ricardo Krause Martinez de SOUZA (iD) https://orcid.org/0000-0003-2161-2666; Pedro Andre KOWACS (iD) https://orcid.org/0000-0001-7770-7475

Correspondence: Rodrigo Tomazini Martins; Neurology department, Gosford Hospital; 60 Holden Street, Gosford, NSW, 2260, Australia; E-mail: rodrigo.tomazinimartins@health.nsw.gov.au

Conflict of interest: There is no conflict of interest to declare.

Received on June 24, 2019; Received in its final form on October 10, 2019; Accepted on November 28, 2019.
} 
An adult has approximately $150 \mathrm{~mL}$ of cerebral spinal fluid (CSF) in the neuroaxis at one time ${ }^{1}$ and it is renewed 3 to 4 times a day ${ }^{2,3}$. CSF is produced continuously at a rate of $0.4 \mathrm{~mL} /$ minute in adults, totaling $500 \mathrm{~mL}$ per day ${ }^{4}$. Therapeutic removal of CSF through the dura-mater was first performed independently by Heinrich Quincke and Walter Wynter in 1891 to relieve raised intracranial pressure $^{5}$. In horizontal decubitus under normal conditions, CSF pressure measured at the lumbar region ranges from 5 to $15 \mathrm{~cm} \mathrm{H}_{2} \mathrm{O}^{6}$.

Although lumbar puncture (LP) is a relatively safe procedure, several adverse effects have been reported, including headache and intracranial hemorrhage ${ }^{7}$. It is a major iatrogenic cause of morbidity in patients who underwent anesthesia, epidural blockage, and diagnostic $L P^{8,9}$. A dural tear yields excessive CSF leakage, leading to intracranial hypotension and reduced CSF volume ${ }^{8,10,1}$; however, dural repair occurs by fibroblastic proliferation of the surrounding tissue and blood clot formation ${ }^{6,12,13}$.

August Bier was the first to report the post-dural puncture headache (PDPH) in 1898,2, after injecting 10-15 mg of cocaine in the subarachnoid space of seven patients ${ }^{11,14,15}$. PDPH diagnosis is based on its clinical presentation and history of previous LP, with evidence of slightly increased CSF protein and lymphocytic pleocytosis in the $\mathrm{CSF}^{16,17}$. In $90 \%$ of PDPH patients, headache ensues within 72 hours post LP and is self-limited ${ }^{1,11}$.

Ever since LP has been routinely performed, PDPH incidence was reported $\sim 66 \%$, ranging from $10-80 \%^{3,13,15}$. The largest cohort of PDPH ever published included 11,000 patients who underwent LP and reported 50\% occurrence $^{11}$. The introduction of atraumatic needles was responsible by a markedly reduction in the incidence of $\mathrm{PDPH}^{8,18,19}$. However, despite the American Academy of Neurology (AAN) recommendations, less than $2 \%$ of neurologists routinely use $\mathrm{it}^{8,12,15,19}$. Yet a variable $10-24 \% \mathrm{PDPH}$ incidence is reported with Quincke needles ${ }^{20,21}$.

Young adults ${ }^{17}$, particularly females, tend to be more affected $(3: 1)^{13}$. A four-fold higher incidence around the fourth decade of life is described ${ }^{2,18}$, while older adults are less susceptible to $\mathrm{it}^{1,15,22}$. PDPH is also infrequent in clinically demented patients ${ }^{23}$ and specifically in normal pressure hydrocepha$\operatorname{lus}^{24}$. A high incidence is also reported among females with low BMI ${ }^{12,19}$ and higher rates of PDPH are reported post LPs performed at emergency departments ${ }^{25}$.

While variable amount of CSF is required for diagnostic tests, samples for fungal culture or tap test require volumes in excess of $30 \mathrm{~mL}^{22,24}$ which can be time consuming. Duration greater than 6 minutes to collect $2 \mathrm{~mL}$ of CSF through a $22 \mathrm{G}$ needle allowing free flow was reported ${ }^{26}$. Although most authors recommend free flow CSF collection, some advocate a mild aspiration by negative pressure can be performed ${ }^{15,19,27,28,29}$. However, safety and tolerability of this technique were never prospectively reported.
The present study aimed to investigate the incidence of PDPH in patients subjected to CSF aspiration during LP, comparing it to the standard technique, as well as to document its safety and tolerability.

\section{METHODS}

\section{Design and participants}

This study included neurological patients who underwent diagnostic LP from February 2010 to December 2012 at Neurological Institute of Curitiba (Brazil). Outpatients who attended the emergency department and inpatients that underwent diagnostic LP were recruited for the study. Subjects had a full anamnesis and neurological examination performed by a staff member followed by any modality of neuroimaging (i.e. CT or MRI brain) to exclude contraindications, prior to the LP was recommended and performed. Exclusion criteria consisted of refusal to take part of the study or consent withdrawal, lack of recent ( $<2$ days) neuroimaging result, blood diathesis, or the presence of other medical contraindication - i.e. anticoagulation, lumbar region skin infection or more than two attempts for a successful LP. All included subjects consented to participate. Study protocol was approved by the local regulatory board.

\section{Lumbar puncture}

LP was performed according to the standard technique adopted within the institution for diagnostic purposes across a wide spectrum of neurological disorders. Patients were positioned in left lateral decubitus with knees flexed and back arched. Antisepsis of the lumbar region was performed; a sterile drape was placed, followed by subcutaneous infiltration of Xylocaine $1 \%$ without vasoconstrictor $(5 \mathrm{~mL})$. A Quincke spinal needle $22 \mathrm{G}$ (Spinocan ${ }^{\circledR}$ ) with metallic stylet was introduced at an angle of $\sim 60^{\circ}$ with the skin at the midline. Bevel was oriented longitudinally and the needle was progressed to the subarachnoid space at the interspace level of L3-L4. In case of failure, only another attempt at L4-L5 was performed after new infiltration with local anesthetic. It was followed by spinal manometry and CSF collection into sterile jars. Outpatients had the CSF collected by free flow, as much as required for the diagnostic tests proposed. Inpatients had CSF collected by mild aspiration via negative pressure with a glass syringe at a rate $3 \mathrm{~mL} /$ minute. Upon collection, a compressive dressing was applied and all subjects were instructed to remain in horizontal decubitus for 60 minutes. All samples were taken immediately to the onsite pathology laboratory for CSF analysis.

\section{Data collection}

Demographic data including sex, age, amount of CSF collected, opening pressure, method of collection, and the 


\section{RESULTS}

A total of 336 patients were eligible for the study (Figure 1). Missing PDPH data amounted to 99 cases (29.5\%), of which 87 were lost follow-up and the remaining were unable to speak $(n=7)$ or recall $(n=5)$. A pattern was identified for the missing BMI data (33.3\%). There was a strong association between missing BMI and missing PDPH data (chi-square=40.276; d.f. $=1 ; \mathrm{p}<0.001$ ), and missing BMI and method of CSF collection (chi-square=27.937; d.f. $=1 ; \mathrm{p}<0.001$ ), with a greater number of participants missing BMI measurements if recruited during an ED presentation (53.9\%) versus

inpatients (24.4\%). Given the study design this is most likely indicative of protocol failure with collecting BMI data during an ED presentation. Information on opening pressure was missing in 19 cases $(5.7 \%)$ but was not significantly associated with PDPH missing values, as none of the other predictors. For these reasons analysis was limited to the participants with complete information on PDPH $(n=237)$ and BMI was excluded from the analysis.

Demographic of subjects and their CSF laboratorial features according to the method of CSF collection are displayed in Table 1. Group CSF aspiration $(n=163)$ had 91 females $(55.8 \%)$ and had median age of 52 years, whereas group free CSF flow ( $n=74)$ was composed of 48 females $(64.8 \%)$ and had a median age of 42 years. Gender difference between groups was not significant $(\mathrm{p}=0.191)$. Aspiration group presented a significantly larger volume of CSF collected than the free flow group $(\mathrm{p}=0.011)$.

Overall $17.7 \%$ of the participants experienced PDPH within the 14 days follow-up period. Breakdown of this value according to the method of CSF collection was $16.5 \%$ of PDPH for aspiration versus $20.2 \%$ for free CSF flow. This difference was not statistically significant ( $\mathrm{p}=0.489$ ). Most of the participants belonged to the younger group aged under $65(\mathrm{n}=176$ vs $\mathrm{n}=61)$. The number of participants with PDPH was much larger in the younger group $(n=37 ; 21 \%)$ than in the older group $(n=5 ; 8 \%)$. The younger participants were significantly more likely to experience PDPH (RR=2.565; CI 1.05-6.229). Univariate analysis results are provided in Table 2. A logistic regression revealed association between volume and the occurrence of PDPH when the method of CSF collection was included in the model. For each additional $1 \mathrm{~mL}$ of CSF collected, the odds of developing PDPH is 6\% higher ( $\mathrm{OR}=1.063$; CI 1.007-1.121; $\mathrm{p}=0.027$ ). Because of small number of cells in the CSF, it was not possible to perform a multivariate analysis including age group and

336 subjects underwent diagnostic LP

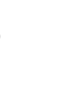

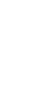

\begin{abstract}
encounter where the procedure occurred were obtained from patients' files. CSF biochemical characteristics were collated from onsite pathology laboratory reports and BMI, when available, was obtained from dietician's reports. BMI data was not available for outpatients. Two weeks after the diagnostic LP, subjects were inquired personally or via phone call about the occurrence of PDPH, as defined by The International Classification of Headache Disorders 2nd edition (ICHD-2) ${ }^{30}$ asking a simple question: "Did you experience headache up to seven days after the diagnostic lumbar puncture, that was triggered a few minutes after assuming upright position and subsided within 30 minutes after reclining?". Dichotomous answers allowed (YES or NO) were recorded.

\section{Statistical analyses}

IBM SPSS v24.0 (IBM Corp., Armonk, NY, USA) was used for data analysis. Missing values analysis and binary indicator ( $0=$ =available, $1=$ =missing) of the variables of interest were used to investigate missing data patterns. Categorical variables such as sex, method of CSF collection, and age group were summarized with numbers (n) and percentages (\%). The normality distribution of the continuous variables such as age, BMI, opening pressure, volume of CSF collected, CSF red blood cell count, mononuclear cell count, and protein levels was investigated using the Shapiro-Wilk test, concluding that all variables are not normally distributed. Descriptive statistics of non-normally distributed variables were expressed as median (interquartile range - IQR). Differences between groups were tested using chi-square and Mann-Whitney test for categorical and continuous non-parametric variables respectively. Logistic regression was used to investigate the relationship between volume of CSF collected and PDPH.

\section{Outcomes}

The primary outcome was to determine the rate of PDPH post CSF aspiration during LP and identify differences in outcomes using individuals and CSF biochemical characteristics. The secondary outcome was to compare the rate of PDPH by free flow versus mild aspiration within the institution and to discuss against the relevant literature available.
\end{abstract}


method of CSF collection. Instead, a subgroup analysis on participants younger than $65(n=176)$ was performed (Table 3). No significant associations emerged when comparing the key parameters in the younger population for the occurrence of PDPH. Finally, there were not statistically significant differences between the methods of CSF collection.

\section{DISCUSSION}

Occurrence of PDPH was found to be similar between the two methods of CSF collection tested. To be consistent, the AAN recommendations of introducing the needle with the bevel oriented longitudinally ${ }^{1,6,15,18}$, reinsertion of the stylet prior to needle withdraw ${ }^{31}$, and avoiding multiple attempts ${ }^{16}$ were followed. Needles 25 to $22 \mathrm{G}$ are recommended for diagnostic LP. The use of $22 \mathrm{G}$ needles were elected for this study, being most suitable for spinal manometry allowing optimal CSF flow ${ }^{6,13,26}$ and widely used. Additionally, larger gauge needles do require less negative pressure to aspirate CSF at the same flow rate, compared to a thinner one. A paramedian

Table 1. Participants' characteristics according to the method of CSF collection.

\begin{tabular}{|c|c|c|c|}
\hline $\begin{array}{l}\text { Method } \\
\text { of CSF } \\
\text { collection }\end{array}$ & $\begin{array}{l}\text { Aspiration } \\
(n=163)\end{array}$ & $\begin{array}{l}\text { Free flow } \\
(n=74)\end{array}$ & $p$-value \\
\hline Female, n (\%) & $91(55.8)$ & $48(64.9)$ & 0.191 \\
\hline $\begin{array}{l}\text { Age (years), } \\
\text { median (IQR) }\end{array}$ & 52 (35-69) & $42(30-54)$ & $0.002^{\star}$ \\
\hline $\begin{array}{l}\text { Age under } 65 \\
\text { years, } n(\%)\end{array}$ & 113 (69.3) & 63 (85.1) & $0.010 *$ \\
\hline $\begin{array}{l}\text { Opening } \\
\text { pressure } \\
\left(\mathrm{cmH}_{2} \mathrm{O}\right) \text {, } \\
\text { median (IQR) }\end{array}$ & $16(13.5-21.0)$ & $\begin{array}{c}17 \\
(13.00-19.00)\end{array}$ & 0.818 \\
\hline $\begin{array}{l}\text { Volume } \\
\text { of CSF } \\
\text { collected } \\
\text { (ml), median } \\
\text { (IQR) }\end{array}$ & $10(5-15)$ & $7(5-10)$ & $0.011 *$ \\
\hline $\begin{array}{l}\text { CSF red } \\
\text { blood cells } \\
\text { count } \\
\left(\times 10^{6} / \mathrm{L}\right) \\
\text { median (IQR) }\end{array}$ & $1(0.3-3.0)$ & $1(0.3-4.0)$ & 0.760 \\
\hline $\begin{array}{l}\text { CSF } \\
\text { Mononuclear } \\
\text { cells count } \\
\left(\times 10^{6} / \mathrm{L}\right) \\
\text { median (IQR) }\end{array}$ & $0(0-0)$ & $0(0-0)$ & 0.858 \\
\hline $\begin{array}{l}\text { CSF protein } \\
\text { level, median } \\
\text { (mg/dl) (IQR) }\end{array}$ & $\begin{array}{c}45.60 \\
(34.20-63.25)\end{array}$ & $\begin{array}{c}41.85 \\
(31.75-65.25)\end{array}$ & 0.391 \\
\hline
\end{tabular}

CSF: cerebrospinal fluid; $\mathrm{CmH}_{2} \mathrm{O}$ : centimeters of water; IQR: interquartile range; *indicates statistically significant. approach was described by some authors to reduce risk of $\mathrm{PDPH}^{2,11}$. However, midline access provides easier identification of anatomical structures and was adopted in the study. That approach has recently not been proved to reduce the risk of PDPH as compared to the latter ${ }^{32}$. Although bed rest post LP had been described to reduce PDPH severity ${ }^{1}$ or delay its onset $^{18}$, several studies failed to prove it to be more effective than early ambulation after LP in the prevention of $\mathrm{PDPH}^{10,33}$. Despite the lack of evidence, we opted for keeping all patients resting in bed post LP for 1 hour.

Concordant with Seupaul and colleagues ${ }^{25}$, we found that PDPH occurred more frequently in those who underwent LP in the emergency department. The incidence reported in this manuscript meets with the commonly reported $30 \%$ incidence of PDPH in this setting ${ }^{16}$. Nonetheless, in those whom the CSF was aspirated, findings were unexpected. The authors hypothesised the incidence of PDPH would be greater with CSF aspiration, when in fact it proved to be marginally lower. Although this difference was not statistically significant, it could be explained by a thicker dural membrane

Table 2. Determinants of PDPH: displaying $p$ values for univariate analysis.

\begin{tabular}{|c|c|c|c|}
\hline Characteristic & $\begin{array}{l}\text { No PDPH } \\
(n=195)\end{array}$ & PDPH $(n=42)$ & $p$-value \\
\hline Female, n (\%) & $111(56.9)$ & $28(66.7)$ & 0.245 \\
\hline $\begin{array}{l}\text { Age (years), } \\
\text { median (IQR) }\end{array}$ & $52.0(31-66)$ & $45.5(35-57)$ & 0.438 \\
\hline $\begin{array}{l}\text { Age under } 65 \\
\text { years, n (\%) }\end{array}$ & 139 (71.3) & 37 (88.1) & 0.024 \\
\hline $\begin{array}{l}\text { Method of CSF } \\
\text { collection }\end{array}$ & & & 0.489 \\
\hline Free Flow, n (\%) & $136(69.7)$ & $27(64.3)$ & \\
\hline Aspiration, n (\%) & $59(30.3)$ & 15 (35.7) & \\
\hline $\begin{array}{l}\text { CSF Opening } \\
\text { pressure } \\
\left(\mathrm{cmH}_{2} \mathrm{O}\right) \text {, } \\
\text { median (IQR) }\end{array}$ & $16(13.0-21.0)$ & $16(13.5-19.5)$ & 0.930 \\
\hline $\begin{array}{l}\text { Volume of CSF } \\
\text { collected (ml), } \\
\text { median (IQR) }\end{array}$ & $10(5-15)$ & $7(5-10)$ & 0.690 \\
\hline $\begin{array}{l}\text { CSF Red } \\
\text { blood cell } \\
\text { count }\left(\times 10^{6} / \mathrm{L}\right) \text {, } \\
\text { median (IQR) }\end{array}$ & $1(0.3-3.6)$ & $1(0.3-2.0)$ & 0.534 \\
\hline $\begin{array}{l}\text { CSF } \\
\text { Mononuclear } \\
\text { cell count } \\
\text { (x106/L), } \\
\text { median (IQR) }\end{array}$ & $0(0-0)$ & $0(0-0)$ & 0.156 \\
\hline $\begin{array}{l}\text { CSF protein } \\
\text { level, median } \\
(\mathrm{mg} / \mathrm{dl})(\mathrm{IQR})\end{array}$ & $\begin{array}{c}46.65 \\
(33.60-66.20)\end{array}$ & $\begin{array}{c}38.85 \\
(34.30-50.10)\end{array}$ & 0.150 \\
\hline
\end{tabular}

PDPH: post-dural puncture headache. 
in those individuals. Amorim and colleagues have already demonstrated that a thinner dura-mater accounts for $50 \%$ higher CSF leakage compared to a thicker one ${ }^{2}$. This phenotype is inherent to individuals and cannot be attributed as a bias of selection. Furthermore, Valença et al. ${ }^{34}$ demonstrated that CSF leakage is variable within an individual as a result of variable dural thickness. These findings have the potential to explain the opposite direction of our findings.

Several studies report increased incidence of PDPH in younger patients, particularly females ${ }^{35,36}$. We found similar trends in our study, however sex did not show to play a role. Also, older age seems to be protective, regardless of the method of CSF collection used. Similar to our findings, low incidence of PDPH in the elderly was also observed by Malm and colleagues ${ }^{22}$.

Unlike other authors who also did not demonstrate any relationship between the amount of CSF collected and PDPH occurrence ${ }^{16,37}$, our findings revealed a slight increase in the occurrence of PDPH. This was not as marked as Hammond and colleagues conclusions ${ }^{12}$, who reported 1.8fold higher risk of PDPH for each extra $5 \mathrm{ml}$ of CSF collected. Additionally, similarly to our findings, recently Monserrate and colleagues $^{38}$ reported a protective effect of collecting CSF volumes of up to $30 \mathrm{~mL}$, albeit safely and tolerably.

Table 3. Results of subgroup analysis (under 65 years).

\begin{tabular}{|c|c|c|c|}
\hline Characteristic & $\begin{array}{c}\text { No PDPH }(n= \\
139,79 \%)\end{array}$ & $\begin{array}{c}\mathrm{PDPH}(n=37, \\
21 \%)\end{array}$ & $p$ value \\
\hline Female, n (\%) & $82(59.0)$ & $27(73.0)$ & 0.120 \\
\hline $\begin{array}{l}\text { Age (years), } \\
\text { median (IQR) }\end{array}$ & $41(27-53)$ & $43(35-52)$ & 0.257 \\
\hline $\begin{array}{l}\text { Method of CSF } \\
\text { collection }\end{array}$ & & & 0.631 \\
\hline Aspiration, n (\%) & 88 (63.3) & $25(67.6)$ & \\
\hline Free Flow, n (\%) & $51(36.7)$ & $12(32.4)$ & \\
\hline $\begin{array}{l}\text { CSF opening } \\
\text { pressure } \\
\left(\mathrm{cmH}_{2} \mathrm{O}\right), \\
\text { median (IQR) }\end{array}$ & $17(14-21)$ & $16(13-20)$ & 0.666 \\
\hline $\begin{array}{l}\text { Volume of CSF } \\
\text { collected (ml), } \\
\text { median (IQR) }\end{array}$ & $7(5-10)$ & $6(5-10)$ & 0.458 \\
\hline $\begin{array}{l}\text { CSF red cell } \\
\text { count (n), } \\
\text { median (IQR) }\end{array}$ & $1.0(0.3-5.0)$ & $1.0(0.3-2.0)$ & 0.500 \\
\hline $\begin{array}{l}\text { CSF } \\
\text { mononuclear } \\
\text { cells count } \\
\left(\times 10^{6} / L\right) \text {, } \\
\text { median (IQR) }\end{array}$ & $0(0-0)$ & $0(0-0)$ & 0.124 \\
\hline $\begin{array}{l}\text { CSF protein } \\
\text { level (mg/dl), } \\
\text { median (IQR) }\end{array}$ & $\begin{array}{c}47.30 \\
(30.80-68.80)\end{array}$ & $\begin{array}{c}37.70 \\
(34.30-47.80)\end{array}$ & 0.282 \\
\hline
\end{tabular}

Alike to Kim and colleagues ${ }^{7}$, we found that the opening pressure measured during spinal manometry in the lateral decubitus was not related to PDPH occurrence.

The term "blood patch" emerged in $1962^{1}$. It alluded that traumatic LP (i.e. "bloody tap" - presence of $>5$ red blood cells $/ \mathrm{mm}^{3}$ of CSF $)^{12}$ was associated with lower incidence of $\mathrm{PDPH}^{6,13}$. This association did not emerge in our sample given the very low red blood cell count in the CSF samples across the two distinct methods of CSF collection.

Finally, the fact that protein levels were not statistically different between the two methods of CSF collection, regardless of the PDPH occurrence or not, suggests that mild aspiration of the CSF may not cause red or white cells lysis. This would be a concern which could invalidate CSF analysis as demonstrated by Chow and Schmidley ${ }^{39}$ from CSF samples obtained from a traumatic LP left for a prolonged period unrefrigerated.

In spite of being the first study ever to investigate the use of this technique for clinical diagnostic LP, when sometimes a large amount of CSF is required, this study has several limitations. Firstly, an observational study design is not ideal. Despite a potential selection bias, an institutional regulation only allowed the use of glass syringes with inpatients. Secondly, there was a substantial amount of missing data, particularly BMI in patients that were not admitted after the procedure, which may have contributed to a less precise analysis. Also, there may be bias of selection of techniques according to the location where patients were first seen by the treating physician and had the LP done. However, these limitations are outweighed by the lack of increased rates of PDPH when comparing both techniques. In contrast, the strengths include the novel investigation and the relatively large cohort analyzed with the technique. Nonetheless, the study may pave the way for future investigations with more rigid protocols targeting for specific age groups, headache onset, intensity, and duration or other features commonly associated with this condition.

Therefore, this study demonstrates that the aspiration of the CSF during LP is not associated with increased rates of PDPH compared to the standard technique (free flow). This adds to safety for performing a mild CSF aspiration, particularly when larger amounts of CSF are required in older patients. This is a valuable technique that could be employed at a busy neurology department, when the ideal conditions are met, without increasing the risk of PDPH.

\section{ACKNOWLEDGEMENTS}

The authors would like to thank all the patients who agreed to participate in this study, the on-site pathology laboratory's (LANAC) staff, the neurology staff who assessed the patients prior to the procedures, and the dieticians who assisted with data collection. 
1. Raymond JR, Raymond PA. Post-lumbar puncture headache. Etiology and management. West J Med. 1988 May;148(5):551-54.

2. Amorim JA, Maciel CM, Damázio Filho O, Aragão MFV, Barros MVG, Silva WF, et al. Cefaléia Pós-Punção Dural: Fisiopatologia, Diagnóstico E Fatores De Risco. Rev Dor. 2007 Abr/Mai/Jun;8(2):1014-27.

3. Lavi R, Rowe JM, Avivi I. Lumbar puncture: it is time to change the needle. Eur Neurol. 2010;64(2):108-13. https://doi. org/10.1159/000316774

4. Ghaleb A, Khorasani A, Mangar D. Post-dural puncture headache. Int J Gen Med. 2012;5:45-51. https://doi.org/10.2147/IJGM.S17834

5. Frederiks JA, Koehler PJ. The first lumbar puncture.J Hist Neurosci. 1997 Aug;6(2):147-53. https://doi.org/10.1080/09647049709525699

6. Turnbull DK, Shepherd DB. Post-dural puncture headache: pathogenesis, prevention and treatment. Br J Anaesth. 2003;91(5):718-729. https://doi.org/10.1093/bja/aeg231

7. Kim SR, Chae HS, Yoon MJ, Han JH, Cho KJ, Chung SJ. No effect of recumbency duration on the occurrence of post-lumbar puncture headache with a 22G cutting needle. BMC Neurol. 2012;12:1. https:// doi.org/10.1186/1471-2377-12-1

8. Alstadhaug KB, Odeh F, Baloch FK, Berg DH, Salvesen R. Post-lumbar puncture headache. Tidsskr Nor Laegeforen. 2012;132(7):818-21. https://doi.org/10.4045/tidsskr.11.0832

9. Dakka Y, Warra N, Albadareen RJ, Jankowski M, Silver B. Headache rate and cost of care following lumbar puncture at a single tertiary care hospital. Neurology. 2011 Jul;77(1):71-4. https://doi.org/10.1212/ WNL.0b013e318220abc0

10. Lin W, Geiderman J. Myth: fluids, bed rest, and caffeine are effective in preventing and treating patients with post-lumbar puncture headache. West J Med. 2002;176(1):69-70. https://doi.org/10.1136/ewjm.176.1.69

11. Spielman FJ. Post-lumbar puncture headache. Headache. 1982;22(6):2803. https://doi.org/10.1111/j.1526-4610.1982.hed2206280.x

12. Hammond ER, Wang Z, Bhulani N, McArthur JC, Levy M. Needle type and the risk of post-lumbar puncture headache in the outpatient neurology clinic. J Neurol Sci. 2011 Jul;306(1-2):24-8. https://doi. org/10.1016/j.jns.2011.04.004

13. Ghaleb A. Postdural puncture headache. Anesthesiol Res Pract. 2010;2010:pii: 102967. https://doi.org/10.1155/2010/102967

14. Bier A. Versuche uber Cocainisirung des Ruckenmarkes. Deutsche Zeitschrift fur Chirurgie. 1899;51:361-9. https://doi.org/10.1007/BF02792160

15. Frank RL. Lumbar puncture and post-dural puncture headaches: implications for the emergency physician. J Emerg Med. 2008 Aug;35(2):149-57. https://doi.org/10.1016/j.jemermed.2007.03.024

16. Ahmed SV, Jayawarna C, Jude E. Post lumbar puncture headache: diagnosis and management. Postgrad Med J. 2006 Nov;82(973):7136. https://doi.org/10.1136/pgmj.2006.044792

17. Bezov D, Lipton RB, Ashina S. Post-dural puncture headache: part I diagnosis, epidemiology, etiology, and pathophysiology. Headache. 2010 Jul;50(7):1144-52. https://doi.org/10.1111/j.1526-4610.2010.01699.x

18. Chohan U, Hamdani GA. Post dural puncture headache.JPMA. 2003;53(8):359-67.

19. Wright BL, Lai JT, Sinclair AJ. Cerebrospinal fluid and lumbar puncture: a practical review.J Neurol. 2012;259(8):1530-45. https:// doi.org/10.1007/s00415-012-6413-x

20. Usmani S, Azmat J, Jameel S, Sirajuddin PG. Post dural puncture headache after spinal anaesthesia and chance of spinal failure: a comparative study using 23G Quincke, 25G Quincke, and 25G Whitacre needle. IOSR. 2016 Jun;15(7):67-71. https://doi. org/10.9790/0853-150736771

21. Chaudry WI, Saleem S, Naaman K, Waseen H, Javaid A, Waseem MB. Comparison of 22, 23 and 25 Gauge Quincke Needles for post dural puncture headache and identification of other significant factors for PDPH in a tertiary care hospital. Proceeding SZPGMI. 2009;23(2):55-60.
22. Malm J, Kristensen B, Karlsson T, Fagerlund M, Elfverson J, Ekstedt J. The predictive value of cerebrospinal fluid dynamic tests in patients with th idiopathic adult hydrocephalus syndrome. Arch Neurol. 1995 Aug;52(8):783-9. https://doi.org/10.1001/ archneur.1995.00540320059013

23. Zetterberg H, Tullhog K, Hansson O, Minthon L, Londos E, Blennow K. Low incidence of post-lumbar puncture headache in 1,089 consecutive memory clinic patients. Eur Neurol. 2010 Jul;63(6):32630. https://doi.org/10.1001/archneur.1995.00540320059013

24. Souza RKM, Rocha S, Martins RT, Kowacs PA, Ramina R. Gait in normal pressure hydrocephalus: characteristics and effects of the CSF tap test. Arq Neuropsiquiatr. 2018;76(5):324-31. http://dx.doi. org/10.1590/0004-282×20180037

25. Seupaul RA, Somerville GG, Viscusi C, Shepard AJ, Hauter WE. Prevalence of postdural puncture headache after ED performed lumbar puncture. Am J Emerg Med. 2005 Nov;23(7):913-5. https://doi. org/10.1016/j.ajem.2005.06.003

26. Carson D, Serpell M. Choosing the best needle for diagnostic lumbar puncture. Neurology. 1996 Jul;47(1):33-7.https://doi.org/10.1212/wnl.47.1.33

27. Fishman RA. Cerebrospinal Fluid in Diseases of the Nervous System. 2nd edition. Philadelphia: Saunders; 1992.

28. Pulec JL. Post lumbar puncture headache.J R Soc Med. 1983;76(1):84.

29. Strachan A, Train J. Lumbar puncture and headache. Aspirating cerebrospinal fluid speeds up procedure. BMJ. 1998 Mar;316(7136):1018-9.

30. Headache Classification Subcommittee of the International Headache Society. The International Classification of Headache Disorders: 2nd edition. Cephalalgia. 2004;24(Suppl 1):9-160. https:// doi.org/10.1111/j.1468-2982.2003.00824.x

31. Strupp M, Brandt T, Müller A. Incidence of post-lumbar puncture syndrome reduced by reinserting the stylet: a randomized prospective study of 600 patients. Journal of neurology. 1998 Sep;245(9):589-92. https://doi.org/10.1007/s004150050250

32. Mosaffa F, Karimi K, Madadi F, Khoshnevis SH, Daftari Besheli L, Eajazi A. Post-dural puncture headache: a comparison between median and paramedian approaches in orthopedic patients. Anesth Pain Med. 2011 Fall;1(2):66-9. https://doi.org/10.5812/ kowsar.22287523.2159

33. Park S, Kim K, Park M, Lee U, Sim HS, Shin IS, et al. Effect of 24Hour bed rest versus early ambulation on headache after spinal anesthesia: systematic review and meta-analysis. Pain Manag Nurs. 2018 Jun;19(3):267-76. https://doi.org/10.1016/j.pmn.2017.10.012

34. Valenca MM, Amorim JA, Moura TP. Why don't all individuals who undergo dura mater/arachnoid puncture develop postdural puncture headache? Anesth Pain Med. 2012;1(3):207-09. https://doi. org/10.5812/kowsar.22287523.3616

35. Kwak KH. Postdural puncture headache. Korean J Anesthesiol. 2017 Apr;70(2):136-43. https://doi.org/10.4097/kjae.2017.70.2.136

36. Wu CL, Rowlingson AJ, Cohen SR, Michaels RK, Courpas GE, Joe EM, et al. Gender and post-dural puncture headache. Anesthesiology. 2006 Sep;105(3):613-8. https://doi.org/10.1097/00000542-200609000-00027

37. González-Martínez F, de León-BelmarJ, Navarro-Gutiérrez S, et al. Disminución en la incidencia de la cefalea pospunción lumbar tras la aplicación de la segunda edición de la Sociedad Internacional de Cefaleas. Rev Neurol. 2005;41(10):582-6. https://doi.org/10.33588/rn.4110.2005161

38. Monserrate AE, Ryman DC, Ma S, Xiong C, Noble JM, Ringman JM, et al. Factors associated with the onset and persistence of post-lumbar puncture headache. JAMA Neurol. 2015 Mar;72(3):325-32. https:// doi.org/10.1001/jamaneurol.2014.3974

39. Chow G, Schmidley JW. Lysis of erythrocytes and leukocytes in traumatic lumbar punctures. Arch Neurol. 1984 Oct;41(10):1084-85. https://doi.org/10.1001/archneur.1984.04050210082020 